\title{
EFFECT OF WORKING CAPITAL MANAGEMENT AND LEVERAGE ON COMPANY VALUE WITH PROFITABILITY AS MODERATING VARIABLES
}

\section{(Empirical Study on Manufacturing Companies Listed on the Indonesia Stock Exchange)}

\author{
${ }^{1 *}$ Shahreen Kasim, ${ }^{2}$ Majied Sumatrani Saragih, ${ }^{3}$ Andri Saifannur \\ ${ }^{1}$ Universitas Tun Hussein Onn Malaysia \\ ${ }^{2}$ Darma Agung University, Medan \\ ${ }^{3}$ Faculty of Economic and Business Universitas Malikussaleh \\ Corresponding Author: shahreenkasim@gmail.com
}

\begin{abstract}
This study aims to determine how the influence of working capital management and leverage on firm value with profitability as a moderating variable. The research method used is quantitative data method. 1) Working Capital Management variable has a positive and significant effect on Firm Value. 2) Leverage variable has no significant effect on firm value. 3) Working Capital Management and Leverage variables have no simultaneous significant effect on Firm Value. 4)Profitability variable is a moderator variable that affects the relationship between Working Capital Management and Firm Value. 5) Profitability variable is not a moderator variable that can moderate the relationship between Leverage and Firm Value.Company value can be used as the basis for making investment decisions because this aspect measures the ability of the company's assets to generate a return on investment made in the company's asset instruments.
\end{abstract}

Keywords : Working Capital Management, Leverage, Profitability and Company Value.

\section{INTRODUCTION}

The value of the company is the same as the value of the shares or the price of the shares where a high company value will be willing to be paid by prospective buyers if the company is sold which is associated with the company's share price (Kusumajaya, 2011:33). The higher the share price in companies listed on the capital market, the higher the wealth of the owners of the company which is reflected in the higher value of the company. Companies that have valueiheight show igood performance achievement so that it becomes a desire ithe owners. The higher the valueicompany, the greater the prosperity that will be received by the owner of the company (Wiagustini, 2013:9).

The value of the company icould imeasured using ifinancial ratio, wrong ithe only one is price to book value (PBV). The PBV ratio isi comparison of the market value of a stock to the book value, iso that it can be seen whether the stock price level is overvalued or undervalued from the book value. The increase in the value of the company is not only determined by the long-term financial policy but the short-term financial policy of the company in this case working capital management. 
The following is iaverage company value chart ion the company iStock-listed manufacturesiIndonesian Securities in the 2015-2019 period:

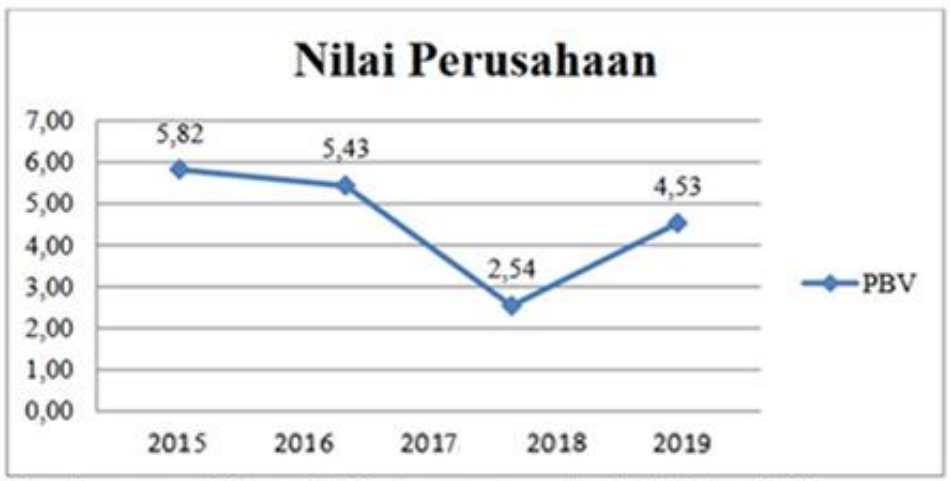

Sumber : www.idx.co.id (Data yang tersedia diolah kembali)

Figure 1.1 Graph of Average Firm Value in Manufacturing Companies Listed on the Indonesia Stock Exchange (IDX) for the 2015-2019 Period.

Based on Figure 1.1, it can be seen that the average development of company value as measured by the Price to Earnings Ratio or share price per share/earnings per share in manufacturing companies listed on the Indonesia Stock Exchange for the period 2016 to 2018 .

Optimal working capital management means minimizing working capital requirements and maximizing company income. If there is too much working capital, it will lead to inefficiency which in turn will have a negative impact on profitability and firm value (Pandey 2010:39). Increasing company value is part of the company's corporate strategy and efficient working capital management is an important element in that strategy (Afza and Nasir: 2007:82).

Consequently, efficient working capital management is a very important factor in maintaining sustainability, liquidity, solvency, profitability and firm value.

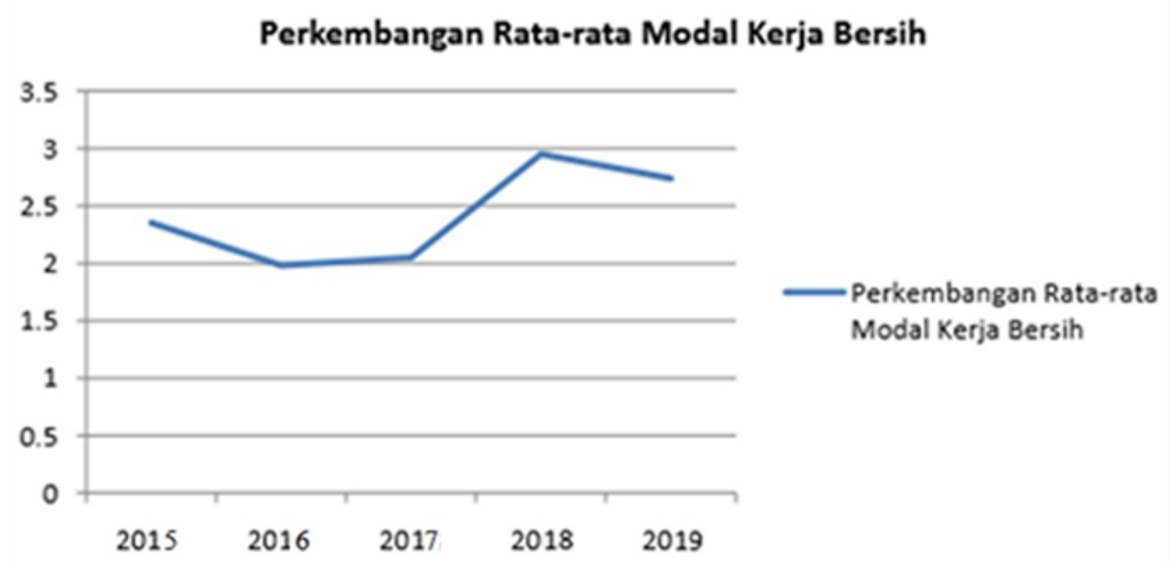

Figure 1.2 Development of Average Net Working Capital Manufacturing sector companies at PT. Indonesia Stock Exchange 2015-2019.

\section{Average Working Capital (In Scale)}

Based on Figure 1.2 above, it shows that there is a fluctuating development of working capital in manufacturing sector companies on the Indonesia Stock Exchange from 2015-2019. 
Leverage is an effect arising from the use of debt as a source of funding company, both short-term funding sources and long-term funding sources. The lower this ratio, the higher the level of corporate funding provided by shareholders. Each company has a different debt policy and debt level. The company's leverage can be influenced by various factors. These factors can be in the form of size, source, income, collateral level, cost of debt, opportunity growth, reputation and liquidity.

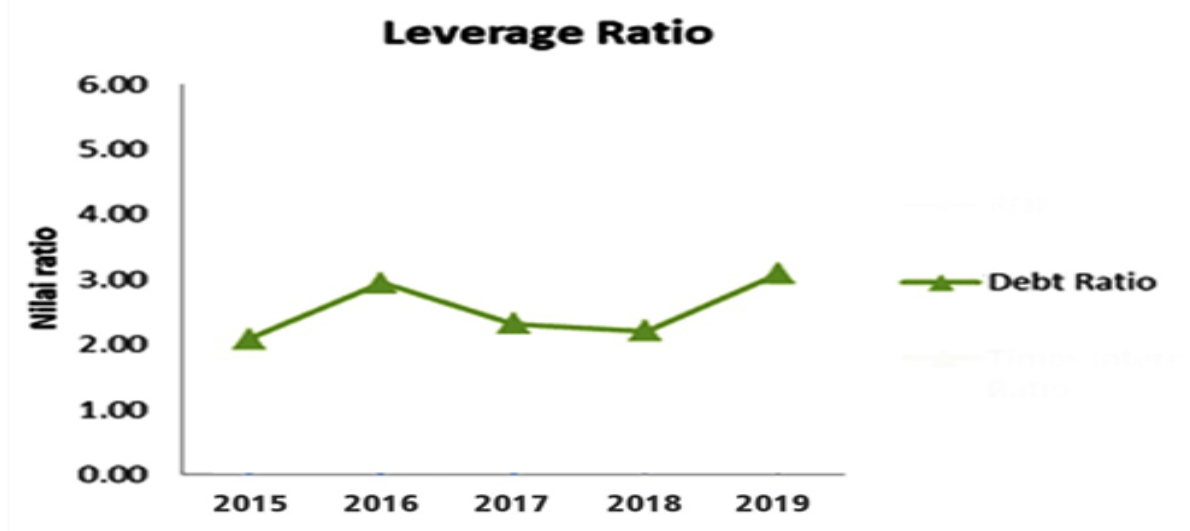

Figure 1.3 Leverage Ratio Graph of Manufacturing Companies Listed on the Indonesia Stock Exchange (IDX) for the 2015-2019 Period

In Figure 1.3 it can be seen that the acquisition of leverage as measured by Total Debt/Total Equity in manufacturing companies listed on the Indonesia Stock Exchange for the 2015-2019 period fluctuated, which experienced an increase and decrease. Kenaiiright and decrease iThis is due to various factors that influence it. Informationi about the cause of risingiThe decline in $\mathrm{k}$ can help investors in making investment decisions. The size is inseparable from the influence of market forces, namelyihigh low permirequests and offers.

Profitability according to Saidi (2004: 120) in Martalina (2011: 104) is the ability of company in making a profit. Investors invest shares in companies to get returns, which consist of yields and capital gains. The higher the ability to earn profits, the greater the return expected by investors, thus making the value of the company gets better. Profitability is an ability the company earns profit in relation to sales, total assets or by capital (equity). In this case it can be explained to find out The profitability of a company is very important for investors and creditors.

In addition to measuring the profit generated by the company, profitability is also used to assess the company's profit position in the previous period and the applicable period, assessing profit developments, and measuring the amount of net profit that will be generated by the company. 


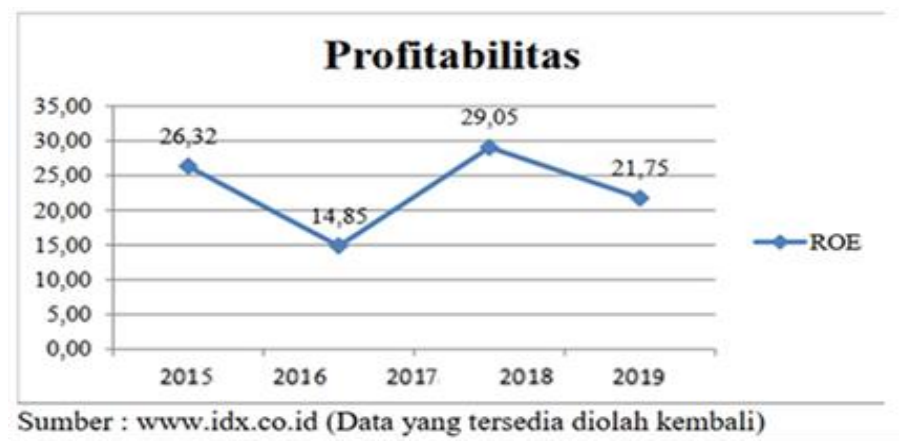

Figure 1.4 Graph of Average Profitability of Manufacturing Companies Listed on the Indonesia Stock Exchange (IDX) for the 2015-2019 Period

Based on Figure 1.4, it can be seen that the average development of profitability as measured by Profit after Tax/Total Assets in manufacturing companies listed on the Indonesia Stock Exchange for the period 2015 to 2016 has fluctuated.

In fact, to get maximum profit results, companies need funds obtained from the company's internal and external processes. Funds obtained from internal companies are in the form of sales made by the company, while funds obtained from external sources are in the form of loans (debts), investments and sales of company shares. To attract investors to invest, the company's assessment can be seen from the level of company profitability as measured by the return on investment in the form of assets (assets) and return on investment in the form of capital.

\section{LITERATURE REVIEW}

\section{Working Capital Management}

Mustafa (2017:69) ManagementWorking capital addresses all aspects of managing current assets and current liabilities. Proper working capital is an important condition for the growth and success of a company for the long term, which will make a profit.

Working capital management is one aspect that must be considered in the company. If If the company cannot maintain a satisfactory level of working capital, it is likely that the company will be in a insolvent state (unable to pay obligations that are due). Current assetimust ibig enough to get icover current liabilities so as to describe a satisfactory level of security (margin of safety).

The company finances and invests in managing and revolving capital, this can reflect the policies made by the company in implementing working capital management. Working capital management aims to manage current assets and current liabilities so as to obtain adequate net working capital and ensure a level of liquidity company (Martono and Harijito, 2001:84).

\section{Leverage}

Leverageis a ratio that projects the state of debt in the company's finances, the following is the understanding of leverage according to several experts: According to Kasmir (2014: 153) "Leverage is a solvency ratio or leverage ratio is a ratio used to measure the extent to which a company's activities are financed with debt." In line with what was expressed by Kasmir. 


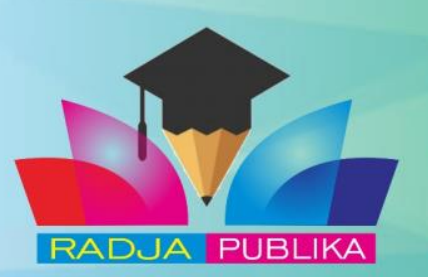

Volume 1 No. 1 (2021)

International Journal of Economic, Business,

Accounting, Acriculture Management and Sharia Administration

This leverage ratio compares the company's overall debt burden to its equity. With wordsiOtherwise, this ratio shows ihow many company assets owned by shareholders icompared to assets owned by icreditor (debtor). If shareholders have more assets, then the company is said to be less leveraged. However, if the creditor (the debtor) owns the majority of the assets, then the company in question is said to have a high level of leverage. The solvency ratio or leverage ratio is very helpful for management and investors to understand how the level of capital structure risk in his company. Leverage ratio and liquidity ratio are ratios to measure ability companies to fulfill their obligations, but both have differences in the period of fulfillment of their obligations. Where the leverage ratio is a ratio that measures the company's ability to meet its long-term obligations, while the liquidity ratio measures the company's ability to meet its short-term obligations or current liabilities such as trade payables and so on.

\section{The value of the company}

Score the company will be reflected in its share price. The market price of the company's shares that is formed between the buyer and the seller at the time of the transaction is called the market value of the company, because the stock market price is considered a reflection of the actual value of the company's assets. iValue companies formed through stock market value indicators are strongly influenced by investment opportunities. Existence Investment opportunities can provide a positive signal about growth company in the future, so that it can increase the value of the company (Susanti, 2010:162).

The higher the stock price, the higher the prosperity of the shareholders, to achieve the value of the company, investors generally submit their management to the shareholders. professional that enterprise value (EV) or also known as firm value (company value) is an important concept for investors, because it is an indicator for the market values the company as a whole.

\section{IMPLEMENTATION METHOD}

Design research is the entire procedure for planning, and implementing research which includes procedures for data collection and data processing that have been determined. In the implementation of a In research, a researcher must develop a research design that is tailored to the type and purpose of the research. In accordance with the research objectives and the nature of the problem to be studied, this research uses quantitative and secondary data. This research places the effect of working capital management, leverage on firm value with profitability as a moderating variable.

\section{Data collection technique}

In this study, researchers conducted several methods of data collection in accordance with the problem under study. Technique The data collection used in this research is the documentation study method.(Sugiyono, 2016:131). Documentation Study is a data collection technique that is not directly addressed to the object of research. Documentation method is data collected fromevidence and documents related to the object of research, in this study in the form of financial statements (financial statements) which were reviewed by the author to be used as material in this study. This method is done by collecting data according to the object to be studied. This method can be done by studying or examining various sources related to research through books, journals and various other written sources as well as on the internet. 


\section{Analysis method}

The method used to support this research is a quantitative and in-depth method This research uses multiple linear regression model. Multiple linear regression model is a model statistical testing that aims to analyze the effect of the independent variable on the dependent variable.The equations that can be arranged in this study are as follows:

$$
\text { Yit }=+1 \text { X1it }+2 \text { X2it }+ \text { eit }
$$

\section{RESULTS AND DISCUSSION}

The data obtained were then tested using the classical assumption test in order to get good results. After the classical assumption test is carried out, the data is analyzed using multiple linear regression analysis techniques and performs hypothesis testing to see the effect of the dependent variable on the independent variable and determines the coefficient of determination to see how big the contribution of the independent variable is to the dependent variable and finally testing the moderating variable.

\section{Classic assumption test}

Before testing the hypothesis in this study, the classical assumption will be tested first. The classical assumption test consists of normality test, multicollinearity test and heteroscedasticity test.

\section{a. Normality test}

Normality test iused to test whether the regression model has a distribution inormal or not. The assumption of normality isivery important requirements on isignificance test (significance), the significance used is $=5 \%$ regression coefficient. Ghazali (2012: 92) states that a good regression model is a regression model that has a normal distribution or is close to normal, so it is feasible to do statistical testing. The normality test used in this study was the Jarque-Bera test. The results of the Jarque-Bera test in this study are as follows:

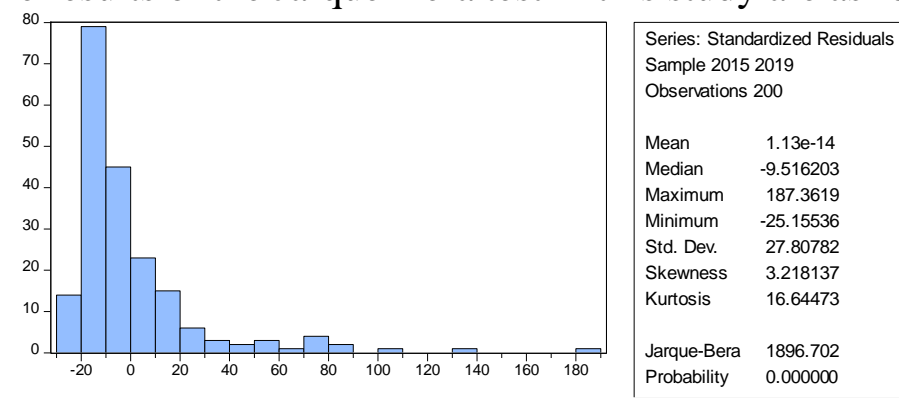

Source: Data processed from attachment (2021)

Figure 4.1 Normality Graph

Based on the picture above, it can be seen that the Jarque-Bera test value is $1,896,702$ and the probability value is 0,000000 where this value is below the standard error tolerance value $(5 \%)$. Therefore, it can be concluded that the normally distributed residuals can be rejected, in other words, the assumption of normally distributed residuals is not met.

\section{b. Multicollinearity Test}

Multicollinearity test aims to test whether in the regression there is a correlation between the independent variables (Independent). If the correlation matrix between the 
independent variables is below 0.8 then multicollinearity does not occur, whereas if the correlation between the independent variables is above 0.8 then multicollinearity occurs.

\section{Table 4.1 Multicollinearity Test Results}

\begin{tabular}{|c|c|c|c|c|}
\hline & $\begin{array}{c}\text { NILAI_PERUSA } \\
\text { HAAN_Y }\end{array}$ & $\begin{array}{c}\text { MODAL_KER } \\
\text { JA_X1 }\end{array}$ & $\begin{array}{c}\text { LEVERAGE } \\
\text { X2 }\end{array}$ & $\begin{array}{c}\text { PROFITABILI } \\
\text { TAS_Z }\end{array}$ \\
\hline $\begin{array}{c}\text { NILAI_PERUSA } \\
\text { HAAN_Y }\end{array}$ & 1 & $\begin{array}{c}- \\
0.00851797734 \\
3360654\end{array}$ & $\begin{array}{c}- \\
0.133654557 \\
969377\end{array}$ & $\begin{array}{c}0.00968218954 \\
2590444\end{array}$ \\
\hline $\begin{array}{c}\text { MODAL_KERJ } \\
\text { A_X1 }\end{array}$ & $\begin{array}{c}- \\
0.0085179773433 \\
60654\end{array}$ & 1 & $\begin{array}{c}0.495088128 \\
3152558\end{array}$ & $\begin{array}{c}- \\
0.09646174003 \\
18729\end{array}$ \\
\hline LEVERAGE_X2 & $\begin{array}{c}- \\
0.1336545579693 \\
77\end{array}$ & $\begin{array}{c}0.49508812831 \\
52558\end{array}$ & 1 & $\begin{array}{c}- \\
0.12760047307 \\
82534\end{array}$ \\
\hline $\begin{array}{c}\text { PROFITABILIT } \\
\text { AS_Z }\end{array}$ & $\begin{array}{c}0.0096821895425 \\
90444\end{array}$ & $\begin{array}{c}- \\
0.09646174003 \\
18729\end{array}$ & $\begin{array}{c}- \\
0.127600473 \\
0782534\end{array}$ & 1 \\
\hline
\end{tabular}

Source: Data processed from attachment 4 (2021)

Based on table 4.6 above, it shows that this model does not show symptoms of multicollinearity by looking at the output between the independent variables in the regression, there is no output that exceeds 0.8 .

\section{c. Heteroscedasticity Test}

The heteroscedasticity test aims to test whether in the regression model there is an inequality of variance and residuals from one observation to another, if the variance of the residuals from one observation to another is fixed then it is called homoscedasticity, and if it is different it is called heteroscedasticity (Ghozali, 2012:101).

Table 4.2. Glejser Test Results

\begin{tabular}{crrrr}
\hline \hline Variable & Coefficient & Std. Error & t-Statistic & Prob. \\
\hline \hline C & 22.57903 & 5.335733 & 4.231664 & 0.0000 \\
MODAL_KERJA_X1 & 0.324657 & 0.325454 & 0.997550 & 0.3197 \\
LEVERAGE_X2 & -7.459352 & 2.955164 & -2.524175 & 0.1124 \\
PROFITABILITAS_Z & 3.131336 & 6.872482 & 0.455634 & 0.6492 \\
\hline & E ffects Specification & & \\
& & & S.D. & Rho \\
\hline \hline Cross-section random & & 11.09357 & 0.2682 \\
Idiosyncratic random & & & 18.32365 & 0.7318 \\
\hline \hline
\end{tabular}

Source: Data processed from attachment 4 (2021)

Based on the table above, it can be seen that all independent variables in the Glajser test are above 0.05 . However, the correlation between profitability and liquidity variables has multicollinearity problems because the correlation matrix is smaller than 0.05 .

\section{d. TestAutocorrelation}

The autocorrelation test aims to test in a model whether or not there is a correlation between the confounding error in period $t$ and the error in period t-1. Ghozali (2012:124) states that a good regression model is a model that does not have autocorrelation in it. 
Table 4.3 Autocorrelation Test Results

\begin{tabular}{|l|r|l|l|}
\hline R-squared & 0.011309 & Mean dependent var & 9.578958 \\
\hline Adjusted R-squared & -0.003824 & S.D. dependent var & 21.87834 \\
\hline SE. of regression & 21.92013 & Sum squared resid & 94176.49 \\
\hline F-statistic & 0.747284 & Durbin-Watson stat & 1.693488 \\
\hline Prob(F-statistic) & 0.525127 & & \\
\hline
\end{tabular}

Source: Data processed from attachment 4 (2021)

The autocorrelation test can be seen from the value of Durbin Watson in this study. The value of Durbin Watson in this study is1.693488and the number of samples is 40 (n), the number of independent variables is $2(\mathrm{k}=2)$, then the Durbin-Watson value, DW 1.693488greater than the upper limit (du) 1.6000 and less (dl) 1.3908, with the table value at a significance level of $5 \%$, it can be concluded that there is no autocorrelation in this regression model, or the calculation can be concluded that the DW value lies in test area. with an upper limit value (du) of 1.6000 and a lower limit (dl) of 1.3908 .

\section{Multiple Linear Regression Analysis}

The method used to support this research is a quantitative method and in this study using multiple linear regression models. Multiple linear regression model is a statistical test model that aims to analyze the effect of the independent variable on the dependent variable.Based on the model selection above, the best model is the Random Effect Model (REM). The results of panel data regression with the Random Effect Model (REM) are as follows:

Table 4.4. Multiple Linear Regression Results

\begin{tabular}{lcccc}
\hline \hline \multicolumn{1}{c}{ Variable } & Coefficient & Std. Error & t-Statistic & Prob. \\
\hline \hline C & 24.37114 & 7.219734 & 3.375629 & 0.0009 \\
MODAL_KERJA_X1 & 0.402925 & 0.414109 & 2.972993 & 0.0001 \\
LEVERAGE_X2 & -5.947743 & 4.085061 & -1.455974 & 0.0470 \\
PROFITABILITAS_Z & 1.074494 & 8.971674 & 0.119765 & 0.9048 \\
\hline \hline R-squared & 0.210309 & Mean dependent var & 9.578958 \\
Adjusted R-squared & 0.380024 & S.D. dependent var & 21.87834 \\
S.E. of regression & 21.92013 & Sum squared resid & 94176.49 \\
F-statistic & 0.747284 & Durbin-Watson stat & 1.693488 \\
Prob(F-statistic) & 0.525127 & & \\
\hline & Unveighted Statistics & \\
\hline \hline
\end{tabular}

Source: Data processed from attachment 4 (2021)

Based on the table above, the regression equation model that can be arranged in this study is as follows: Firm Value $=24.37+0.40$ Working Capital Management -5.94 Leverage + 1.07Profitability $+\mathrm{e}$ 


\section{Determination Test}

The coefficient of determination is used to see how much the independent variable contributes to the dependent variable. In other words, the value of the determinant coefficient is used to measure the contribution of the studied variables $\mathrm{X}$ and $\mathrm{Y}$ as the dependent variables.

Table 4.5 Determination Test

\begin{tabular}{|c|c|c|c|}
\hline R-gualad & 0210509 & Mesn dependert. var & 9.576958 \\
\hline Adusked $R$-gquared & 0.560024 & S D. deparderit war & 218793 \\
\hline SE of regrassion & 21.92013 & Sum squarod rasid & 94170.49 \\
\hline F-gutetic & 0.747284 & Durbin-Wa son sai: & $1.6958 \mathrm{~s}$ \\
\hline Piola(F-sulstic) & 0.525127 & & \\
\hline
\end{tabular}

Based on table 4.9, it can be seen that the adjusted $\mathrm{R}$ square value is 0.380 or $38.0 \%$, this shows that the . testdetermination carried out to determine good accuracy in the analysis indicated by the magnitude of the coefficient of determination adjusted $R$ square.

\section{Hypothesis testing}

\section{1. $t$ test (Partial)}

The $t$ test is used to see the effect of the independent variable on the dependent variable partially. The results of hypothesis testing carried out, it can be concluded that the partial test in this study is feasible to use if the decision-making criteria with the ttable value then also look at the probability value.

Table 4.6. Partial Test (t)

\begin{tabular}{crrrr}
\hline \hline Variable & Coefficient & Std. Error & t-Statistic & Prob. \\
\hline \hline C & 24.37114 & 7.219734 & 3.375629 & 0.0009 \\
MODAL_KERJA_X1 & 0.402925 & 0.414109 & 2.972993 & 0.0001 \\
LEVERAGE_X2 & -5.947743 & 4.085061 & -1.455974 & 0.0470 \\
PROFITABILITAS_Z & 1.074494 & 8.971674 & 0.119765 & 0.9048 \\
\hline \hline
\end{tabular}

Source: Data processed from attachment 4 (2021)

a. The Effect of Working Capital Management (X1) on Firm Value (Y).

Based on the test results using the Eviews 10 application, it is known that the tcount value of Working Capital Management is 2.972993 significantly 0.0001 . The ttable value in this study is calculated by $\mathrm{df}=40-\mathrm{k}$ (38) which is 2.0243 with a significance of 0.05 . So it can be seen that working capital management has a positive and significant effect on firm value. This is indicated by the results of the tcount (2.972993) $>t$ table (2.0243) and the significant value is $0.0001<0.05$.

b. The Effect of Leverage (X2) on Firm Value (Y).

Based on the test results using the Eviews 10 application, it is known that the tcount value of Leverage is-1.455974 significantly 0.0470 . The ttable value in this study is calculated by $\mathrm{df}=40-\mathrm{k}$ (38) which is 2.0243 with a significance of 0.05 . So it can be seen that Leverage has a negative and insignificant effect on Firm Value. This is indicated by the results of the tcount $(-1.455974) \mathrm{t}$ table $(2.0243)$ and significant value $0.0470<0.05$. So it can 
be concluded that the leverage variable has no significant effect on firm value in manufacturing companies listed on the Indonesian stock exchange.

\section{F Test (Simultaneous)}

The $\mathrm{f}$ test is used to see the effect of the independent variable on the dependent variable simultaneously or simultaneously.

Table 4.7. Simultaneous Test Results (F)

\begin{tabular}{lrll}
\hline \hline R-squared & 0.011309 & Mean dependent var & 9.578958 \\
Adjusted R-squared & -0.003824 & S.D. dependent var & 21.87834 \\
S.E. of regression & 21.92013 & Sum squared resid & 94176.49 \\
F-statistic & 0.747284 & Durbin-Watson stat & 1.693488 \\
Prob(F-statistic) & 0.525127 & \\
\hline \hline
\end{tabular}

Source: Data processed from attachment 4 (2021)

a. The Effect of Working Capital Management (X1) and Leverage (X2) Simultaneously Affecting Firm Value (Y).

Based on the test results using the Eviews 10 application, it is known that the Fcount value is 0.747284 with a significant 0.525127 . The ftable value in this study calculated by df $=40-\mathrm{k}-1$ (37) is 3.25 with a significance of 0.05 . So it can be seen that Working Capital Management and Leverage have a positive and insignificant effect simultaneously on Firm Value. This is indicated by the results of the tcount (0.747284) $<t$ table (3.25) and significant value $0.525127>0.05$. So it can be concluded that the variables of Working Capital Management and Leverage have no simultaneous significant effect on firm value in manufacturing companies listed on the Indonesia Stock Exchange.

\section{Moderate Effect Test}

Moderating variables or moderating variables are variables that can influence (strengthen or weaken) the relationship between the independent variable and the dependent variable. (Erlina, 2011:88). The moderating variable (Z) in this study is Profitability which will be tested whether it can affect the relationship between the dimensions of the Working Capital Management and Leverage variables on Firm Value.

\section{Table 4.8 ResultsModerate Effect Test}

\begin{tabular}{crrrr}
\hline \hline Variable & Coefficient & Std. Erro & t.Statistic & Prob. \\
\hline \hline C & 24.84046 & 8.698099 & 2.855849 & 0.0048 \\
MODAL_KERJA_X1 & 2.142374 & 1.359822 & 1.575713 & 0.1167 \\
LEVERAGE_X2 & -12.31595 & 7.702733 & -1.598907 & 0.1115 \\
PROFITABILITAS_Z & 5.590352 & 15.01735 & 0.372260 & 0.7101 \\
MODAL_KERJA_X1+PROFITABILITAS_Z & -4.515649 & 3.401870 & -1.327373 & 0.0159 \\
LEVERAGE_X2*PROFITABIUTAS_Z & 10.28593 & 12.70870 & 0.809362 & 0.4193 \\
\hline \hline
\end{tabular}

Source: Data processed from attachment 4 (2021)

a. Profitability (Z) Moderates Relationship of Working Capital Management (X1) to Firm Value (Y).

It is known that the MRA coefficient value from the interaction of Working Capital Management_Profitability to Firm Value is negative, namely -4.515549 with Tcount $1.327373<2.0243$ and $\mathrm{p}$-value $0.0159<0.05$, this indicates that the Profitability variable is a 
moderator variable that affects the relationship between Working Capital Management and Firm Value.

b. Profitability (Z) Moderates Leverage Relationship (X2) to Firm Value (Y).

It is known that the MRA coefficient value from the Leverage_Profitability interaction with the Firm Value is positive, namely 10.28593 with Tcount $0.809362<2.0243$ and p-value $0.4193>0.05$, this shows that profitability is not a moderating variable that can moderate the relationship between Leverage and Firm Value.

\section{Discussion}

Working capital management in the company will always rotate in accordance with the company's operating turnover. The working capital turnover period begins when capital is invested into working capital components, through the operating process until the funds return to cash, the shorter the operating process, the faster the working capital turnover rate.

a iCompanies that have debt will have a burdenifixed finance, interest and credit returns and thusilead the company into liquidation. As a result,icompanies have a tendency to payimore dividends ilow to maintain liquidity and flow positionigood cash. By adaptingiagency theory, ithe existence of dividends paid by the company becomes a substitute mechanism for controlling agency conflicts due to the acquisition of leverage and profitability.

One of the means iAn economy that is managed together to maximize profit and value is a company. iThe success of a company can be seen from the ability iworking capital management and leverage management in seeing future opportunities. To achieve the company's goals, a good management of the company's working capital is needed.

\section{CONCLUSION}

To complete this research, there are several additional aspects proposed in the suggestions in this study, namely as follows:

a) Expected on Manufacturing Company listed on the Indonesia Stock Exchange to always maintain the value of the company, and this research should be used as a strategy or as material for consideration so that Manufacturing companies pay attention to company values in carrying out company activities. This means that the Manufacturing Company, while maintaining good corporate values. This is in order to be able to significantly increase the value of the company.

b) Paying attention to Working Capital Management, Leverage, Profitability and especially Company Value because this aspect is very attractive to investors in conducting technical analysis and predicting the movement of the company's stock price. It will be even more interesting if the company has a good corporate value. So that investors can find out risk analysis and predict the value of the company, of course investors will be interested in investing their funds in the company.

c) Company value can be used as the basis for making investment decisions because this aspect measures the ability of the company's assets to generate a return on investment made in the company's asset instruments.

d) It is recommended for further researchers to expand the scope of the object of research so that later the results of this study can contribute thoughts, information and considerations to the manufacturing company in determining policies, in making working capital 
management strategies and leverage so that the company able to increase the value of the company.

\section{REFERENCES}

\section{Books}

Ghozali, Imam. (2012), Application of Multivariate Analysis with EViews Program. Semarang : Diponegoro University Publishing Agency.

Kasmir, (2014). Financial Statement Analysis, 7th printing. Jakarta: PT Raja Grafindo Persada.

Mustafa, (2017). Financial Management, Yogyakarta: CV ANDI OFFSET Publisher.

Sugiyono (2016). Combination Research Methods (Mix Methods). Bandung: Alphabeta.

Susanti, I., (2010), Personnel and Academic Information System at SMA NEGERI 19 Surabaya Based on PHP, ITS, Surabaya.

\section{Journal}

Afza, T. and MS Nazir, (2007). Working Capital Management Policies of Firms: Empirical Evidence from Pakistan. Conference Proceedings of 9th South Asian Management Forum (SAMF) on February 24-25, North South University, Dhaka, Bangladesh.

Cen, C. C., Cahyadi, W., Cahyadi, L., Candrasa, L., Sinurat, M., Ilham, R. N., \& Saputra, J. Factors that Affect Competence and Affective Commitment and Its implication on Job Performance: A Case Study of STIE Medan, Indonesia.

Kusumajaya. (2011). Journal of Accounting: 'The Effect of Capital Structure \& Company Growth on Profitability \& Firm Value in Manufacturing Companies on the Indonesia Stock Exchange'.

Martalina, Lifessy. (2011). The Effect of Profitability and Firm Size on Firm Value With Capital Structure as an Intervening Variable. Accounting Thesis, Faculty of Economics, Padang State University.

Pandey, RR, Dubey, RC \& Saini, S., (2010), Phytochemical and Antimicrobial Studies on essential Oils of Some Aromatic Plants, African Journal of Biotechnology, 9(28), 4364-4368.

ST. Maryam, Rachma Atamimi, Eko Sumartono, Dwi Orbaningsih, Riinawati (2020) GLOBAL FINANCIAL CRISIS MANAGEMENT BY HUMAN RESOURCE MANAGEMENT. Journal of Critical Reviews, 7 (1), 287-290. doi:10.31838/jcr.07.01.53 
Wiagustini, Luh Putu. (2013). Fundamentals of Financial Management. Denpasar: Udayana University Press. 